\title{
Ultrathin Surface Coatings for Improved Electrochemical Performance of Lithium Ion Battery Electrodes at Elevated Temperature
}

\author{
Jianqing Zhao and Ying Wang* \\ Department of Mechanical Engineering, Louisiana State University, Baton Rouge, Louisiana 70803, United States
}

Supporting Information

ABSTRACT: To enhance the cycling stability of $\mathrm{LiMn}_{2} \mathrm{O}_{4}$ especially at elevated temperature, we use the atomic layer deposition (ALD) method to deposit ultrathin and highly conformal $\mathrm{ZnO}$ coatings (as thin as $0.34-1.7 \mathrm{~nm}$ ) onto $\mathrm{LiMn}_{2} \mathrm{O}_{4}$ cathodes with precise thickness-control at atomic scale. We prepare two types of ALD-modified electrodes: one is an electrode composed of $\mathrm{ALD}$-coated $\mathrm{LiMn}_{2} \mathrm{O}_{4}$ particles and uncoated carbon/polyvinylidenefluoride (PVDF) network; the other is ALD-coated $\mathrm{LiMn}_{2} \mathrm{O}_{4}$ composite electrode. All ALD-modified $\mathrm{LiMn}_{2} \mathrm{O}_{4}$ electrodes demonstrate significantly enhanced cycling performances than bare electrodes at both 25 and $55{ }^{\circ} \mathrm{C}$. In particular, the electrode coated with $6 \mathrm{ZnO}$ ALD layers (1.02 nm thick) shows the best cycling performances among electrodes coated with ALD films of different thicknesses at both 25 and $55{ }^{\circ} \mathrm{C}$, indicating cycling performances of coated electrodes can be easily optimized by accurately tuning coating thickness via varying ALD growth cycles. Furthermore, an electrode consisting of $\mathrm{LiMn}_{2} \mathrm{O}_{4}$ particles coated with $6 \mathrm{ZnO}$

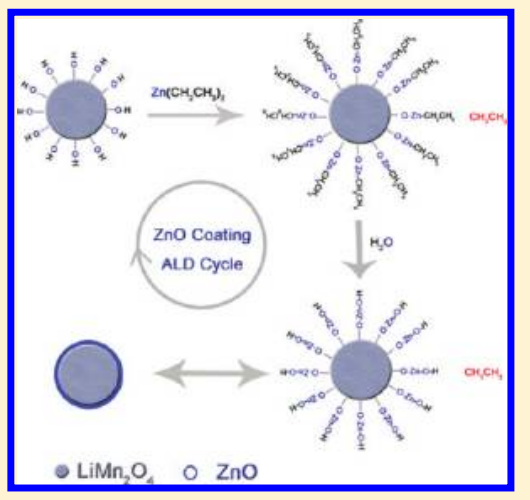
ALD layers and uncoated carbon/PVDF network shows even better electrochemical performances than an electrode coated with $6 \mathrm{ZnO} \mathrm{ALD}$ layers at both 25 and $55^{\circ} \mathrm{C}$. The enhanced electrochemical performances of ALD-coated cathodes are ascribed to the high-quality ALD coatings that are highly conformal, dense, complete, and thus effectively protect active material from Mn dissolution especially at elevated temperature.

\section{INTRODUCTION}

Lithium manganese oxide $\left(\mathrm{LiMn}_{2} \mathrm{O}_{4}\right)$ has been considered as a promising cathode alternative to the commercial lithium cobalt oxide $\left(\mathrm{LiCoO}_{2}\right)$ for rechargeable lithium ion batteries (LIBs) due to its nontoxicity, low cost, and excellent rate capability for applications in portable electronic devices and plug-in electric vehicle. ${ }^{1,2}$ However, this electrode material suffers from the $\mathrm{Mn}$ dissolution, crystal structure transformation, and electrolyte decomposition during electrochemical cycling, especially at the elevated temperature. The poor capacity retention of $\mathrm{LiMn}_{2} \mathrm{O}_{4}$ cathode material limits its practical applications. ${ }^{3-6} \mathrm{Mn}$ dissolution during electrochemical cycling is caused by the attack from the acidic hydrofluoric acid (HF) formed by the residual $\mathrm{H}_{2} \mathrm{O}$ and hexafluorophosphate $\left(\mathrm{LiPF}_{6}\right)$ in the electrolyte. This irreversible decomposition of $\mathrm{LiMn}_{2} \mathrm{O}_{4}$ yields impurity phases of the rock salt phase $\left(\mathrm{Li}_{2} \mathrm{MnO}_{3}\right)$ and tetragonal phase $\left(\mathrm{Li}_{2} \mathrm{Mn}_{2} \mathrm{O}_{4}\right)$, which is the key factor for the capacity fading. ${ }^{7,8}$ Phase transition of the spinel $\mathrm{LiMn}_{2} \mathrm{O}_{4}$ also occurs, and the crystal structure of $\mathrm{LiMn}_{2} \mathrm{O}_{4}$ changes from the cubic to tetragonal symmetry during long-term cycling. Such structural degradation resulted from the Jahn-Teller effect considerably increases the disorder of lithium ions. ${ }^{9}$ The strong oxidation ability of $\mathrm{Mn}^{4+}$ at the end of charge reaction will bring about the decomposition of electrolyte on the surface of the working electrode. The formed solid electrolyte interphase (SEI) can cause increased charge transition resistance and distinct electrochemical polarization on the electrode. ${ }^{2}$ The factors mentioned above will together result in poor capacity retention of $\mathrm{LiMn}_{2} \mathrm{O}_{4}{ }^{7}$

The surface modification technique has been reported as an effective approach to improve the cycling performance of $\mathrm{LiMn}_{2} \mathrm{O}_{4}$ by coating different conductive carbon materials, phosphates, amphoteric oxides, and composite oxides. ${ }^{3-5,10-14}$ In order to circumvent the key issue of $\mathrm{Mn}$ dissolution for $\mathrm{LiMn}_{2} \mathrm{O}_{4}$, various oxides such as $\mathrm{Al}_{2} \mathrm{O}_{3}, \mathrm{ZnO}, \mathrm{ZrO}_{2}, \mathrm{MgO}$, $\mathrm{SiO}_{2}, \mathrm{TiO}_{2}, \mathrm{Cr}_{2} \mathrm{O}_{3}$, and $\mathrm{SnO}_{2}$ have been employed as surface coatings to protect $\mathrm{LiMn}_{2} \mathrm{O}_{4}$ particles from the HF's attack in electrolyte. ${ }^{6-9,15-22}$ The oxide coating on $\mathrm{LiMn}_{2} \mathrm{O}_{4}$ scavenges trace hydrogen fluoride acids (HF) in LIBs, and thus slows down dissolution of manganese ions and degradation of organic electrolyte at cathode, resulting in better electrochemical performance of $\mathrm{LiMn}_{2} \mathrm{O}_{4}$. Most surface modifications of lithium transition metal oxides reported in literature are carried out with wet chemical methods such as sol-gel processing or solution processing, ${ }^{5,23}$ such as soaking cathode materials into a nanoalumina sol. ${ }^{24}$ Other methods include melting impregnation method and pulsed laser deposition. ${ }^{20,25}$ However, these methods are not well-controlled processes. The resulted coatings lack conformality, uniformity, and completeness. One is not capable of controlling or tuning the coating

Received: February 1, 2012

Revised: May 4, 2012

Published: May 15, 2012 
thickness and quantity by using these methods, which limits the repeatability, reliability, and optimization of these processes. Moreover, wet chemistry methods require a large amount of solvent and precursor and a postheat-treatment to obtain the desired coatings. In addition, nanostructured battery electrodes have received tremendous attention lately, owning to their high surface area and high capacities. However, coatings resulted from wet processing are usually $50-100 \mathrm{~nm}$ thick, ${ }^{26}$ which is too thick to be coated onto nanostructured electrodes. Moreover, the conventional thick oxide coatings on the cathode materials would hinder $\mathrm{Li}$ ion diffusivity, resulting in both low energy and power density of the working electrodes. ${ }^{27}$ Therefore, it is necessary to explore new surface coatings that are much thinner and have high conformality for nextgeneration battery technology.

In this study, we deposit ultrathin and highly conformal oxide coatings onto $\mathrm{LiMn}_{2} \mathrm{O}_{4}$ by using the atomic layer deposition (ALD) method with precise thickness control at atomic scale. ALD requires only a minimal amount of precursor and can be used to deposit ultrathin and highly conformal surface coatings. ${ }^{28,29}$ The basic advantage of ALD lies in the fact that the film growth is surface controlled, rather than source controlled as in many other deposition methods such as chemical vapor deposition (CVD). This is achieved by using sequential exposures, separating the (usually binary) reaction between the precursor compounds into two half-reactions. During each half-reaction, only one monolayer of the reactant chemisorbs (or is chemically bound) on the surface. Further layers that are only physisorbed are removed by an inert gas purge before the other reactant is introduced. As a result, the process proceeds stepwise in self-limiting surface reactions, separated by purge steps. Hence, films grown using ALD are typically uniform, dense, homogeneous, pinhole-free, and extremely conformal to the underlying substrate. Moreover, ALD has excellent step coverage $(\sim 100 \%)$ and refilling ability on particles and porous structures. ${ }^{27,29-31}$

To date, there are only a few reports about surface modifications of lithium ion battery electrodes via ALD coatings and most of them focused on $\mathrm{LiCoO}_{2}{ }^{32-39}$ To the best of our knowledge, there is no report about the effect of ALD coatings on electrochemical properties of $\mathrm{LiMn}_{2} \mathrm{O}_{4}$ so far, except a communication paper we published recently. ${ }^{6}$ In the present work, we fabricate $\mathrm{ZnO}$ ALD modified $\mathrm{LiMn}_{2} \mathrm{O}_{4}$ cathodes to enhance cycling performances of cathodes at both room temperature $\left(25^{\circ} \mathrm{C}\right)$ and elevated temperature $(55$ $\left.{ }^{\circ} \mathrm{C}\right)$. The $\mathrm{ZnO} \mathrm{ALD}$ coatings are either deposited onto individual $\mathrm{LiMn}_{2} \mathrm{O}_{4}$ particles or onto an entire $\mathrm{LiMn}_{2} \mathrm{O}_{4}$ composite electrode. Both of these two types of ALD-modified cathodes show enhanced cycleability compared to bare cathodes at room temperature and elevated temperature. Furthermore, cycling performances of coated cathodes are optimized by manipulating the coating thickness via varying ALD growth cycles. Electrode composed of $\mathrm{LiMn}_{2} \mathrm{O}_{4}$ particles coated with $6 \mathrm{ZnO}$ ALD layers shows the best cycling performance even at the elevated temperature $\left(55^{\circ} \mathrm{C}\right)$, which can be considered as a very promising electrode applied to the elevated temperature environment.

\section{EXPERIMENTAL SECTION}

Sample Preparation. Atomic layer deposition of $\mathrm{ZnO}$ coatings on $\mathrm{LiMn}_{2} \mathrm{O}_{4}$ particles (Alfa Aesar, 99.5\%) was carried out in a Savannah 100 ALD system (Camabridge NanoTech Inc.) at $120{ }^{\circ} \mathrm{C}$ using $\mathrm{Zn}\left(\mathrm{CH}_{2} \mathrm{CH}_{3}\right)_{2}$ (diethylzinc, DEZ) and
$\mathrm{H}_{2} \mathrm{O}$ as precursors with exposure time of $0.015 \mathrm{~s}$, waiting time of $5 \mathrm{~s}$, and purge time of $40 \mathrm{~s}$. The principle of $\mathrm{ZnO}$ ALD growth from $\mathrm{H}_{2} \mathrm{O}$ and $\mathrm{DEZ}$ is subjected to the two selfterminating reactions as follows: ${ }^{36,40,41}$

$$
\begin{aligned}
& \mathrm{ZnOH}^{*}+\mathrm{Zn}\left(\mathrm{CH}_{2} \mathrm{CH}_{3}\right)_{2} \\
& \quad \rightarrow \mathrm{ZnO}-\mathrm{ZnCH}_{2} \mathrm{CH}_{3}^{*}+\mathrm{CH}_{3} \mathrm{CH}_{3} \\
& \mathrm{ZnCH}_{2} \mathrm{CH}_{3}^{*}+\mathrm{H}_{2} \mathrm{O} \rightarrow \mathrm{ZnOH}^{*}+\mathrm{CH}_{3} \mathrm{CH}_{3}
\end{aligned}
$$

$\mathrm{LiMn}_{2} \mathrm{O}_{4}$ particles were coated with 2, 6, 10, and $50 \mathrm{ZnO}$ ALD layers via corresponding ALD growth cycles, respectively.

Electrode Fabrication. The bare composite electrodes (abbreviated as B-E) were composed of $80 \%$ bare $\mathrm{LiMn}_{2} \mathrm{O}_{4}$ particles, $10 \%$ acetylene black (conductive carbon, Alfa Aesar, 99.5\%), and $10 \%$ polyvinylidenefluoride (PVDF, Alfa Aesar) as the binder, dissolved in N-methyl-2-pyrrolidone (NMP) solvent. The resultant viscous slurry was coated onto the aluminum current collector using the AFA-III automatic film applicator (MTI) with the thickness setting of $500 \mu \mathrm{m}$ and then dried at $120{ }^{\circ} \mathrm{C}$ overnight under vacuum. The dried electrodes were pressed to an effective thickness of $50 \mu \mathrm{m}$ by using the EQ-MR100A rolling press machine (MTI). Approximately 10 $\mathrm{mg}$ of active material was loaded in the circular working electrode with a diameter of $18.9 \mathrm{~mm}$. The bare composite electrodes were coated with 2, 6, and $10 \mathrm{ZnO}$ ALD layers, respectively (abbreviated as $2 \mathrm{ZnO}$ ALD-E, $6 \mathrm{ZnO}$ ALD-E, and $10 \mathrm{ZnO}$ ALD-E). Other comparative composite electrodes were prepared by mixing $\mathrm{LiMn}_{2} \mathrm{O}_{4}$ particles coated with 2,6 , and $10 \mathrm{ZnO}$ ALD layers with conductive carbon and PVDF binder at the same weight ratio of $80: 10: 10$, respectively (abbreviated as $2 \mathrm{ZnO}$ ALD LMO-E, $6 \mathrm{ZnO}$ ALD LMO-E, and $10 \mathrm{ZnO}$ ALD LMO-E).

Characterizations. The crystallographic structure of bare and $\mathrm{ZnO}$ ALD coated $\mathrm{LiMn}_{2} \mathrm{O}_{4}$ powders were examined by using a Rigaku MiniFlex X-ray diffractometer with $\mathrm{Cu} \mathrm{K}_{\alpha}$ radiation at a scan rate of $4^{\circ} / \mathrm{min}$. The particle size and surface morphology were observed using a FEI Quanta 3D FEG field emission scanning electron microscopy (FESEM). Transmission electron microscopy (TEM) images were captured on a JEM-2010 microscopy at an acceleration voltage of 200 $\mathrm{kV}$, to investigate the characteristics of the $\mathrm{ZnO}$ coatings. Surface compositions of $\mathrm{LiMn}_{2} \mathrm{O}_{4}$ particles coated with $6 \mathrm{ZnO}$ ALD layers and $\mathrm{LiMn}_{2} \mathrm{O}_{4}$ composite electrode coated with 6 $\mathrm{ZnO} \mathrm{ALD}$ layers were analyzed via $\mathrm{X}$-ray photoelectron spectroscopy (XPS) using an AXIS 165 spectrometer with a twin-anode $\mathrm{Al} \mathrm{K} \mathrm{K}_{\alpha}(1486.6 \mathrm{eV}) \mathrm{X}$-ray source. All the XPS spectra were calibrated according to the binding energy of the C1s peak at $284.8 \mathrm{eV}$.

Electrochemical Measurements. Different $\mathrm{LiMn}_{2} \mathrm{O}_{4}$ based composite electrodes were integrated into two-electrode CR2032-type coin cells for electrochemical measurements, with $\mathrm{LiMn}_{2} \mathrm{O}_{4}$-based composite electrode as cathode, metallic lithium foil as anode, and Celgard-2320 membrane as separator; the electrolyte was $1 \mathrm{M} \mathrm{LiPF}_{6}$ dissolved in ethylene carbonate (EC), dimethyl carbonate (DMC), and diethyl carbonate (DEC) at a volumetric ratio of $1: 1: 1$. The coin cells were assembled in an argon-filled glovebox (OMNI-Lab system, Vacuum Atmosphere Co.). Galvanostatic charge and discharge were performed in a voltage range of 3.4-4.5 $\mathrm{V}$ at a current density of $120 \mathrm{~mA} / \mathrm{g}$ using an 8-channel battery analyzer (MTI Corporation) at room temperature $\left(25^{\circ} \mathrm{C}\right)$ and elevated temperature $\left(55^{\circ} \mathrm{C}\right)$. Electrochemical specific storage 


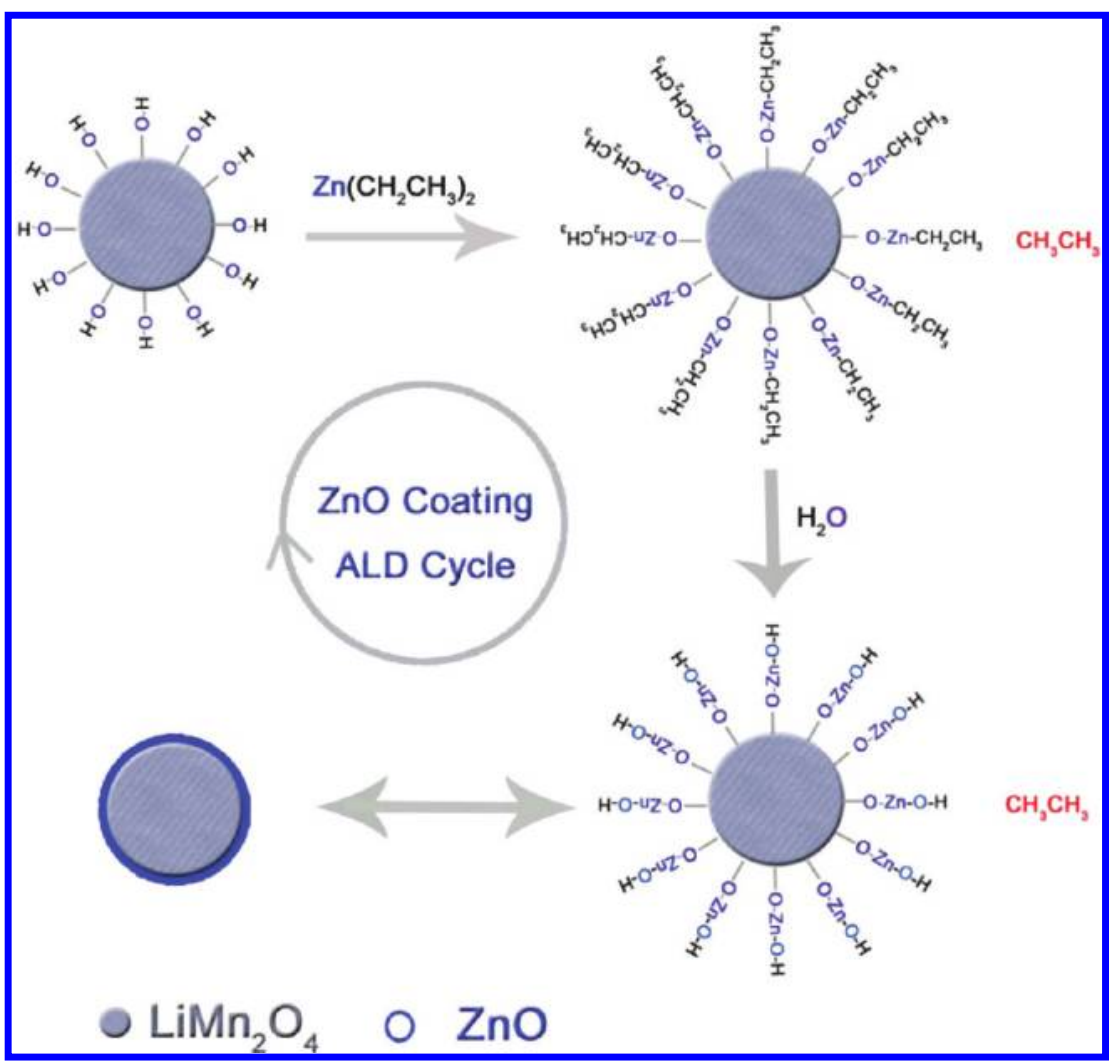

Figure 1. Schematic representation for $\mathrm{ZnO}$ ALD growth on the surface of $\mathrm{LiMn}_{2} \mathrm{O}_{4}$ particle using $\mathrm{Zn}\left(\mathrm{CH}_{2} \mathrm{CH}_{3}\right)_{2}$ and $\mathrm{H}_{2} \mathrm{O}$ as precursors.

capacities of working electrodes were calculated based on the mass of cathode materials. In addition, cyclic voltammetry (CV) curves of $6 \mathrm{ZnO}$ ALD LMO-E were measured at a scan rate of $0.1 \mathrm{mV} \mathrm{s}^{-1}$ between 3.4 and $4.5 \mathrm{~V}$ using an electrochemical analyzer (CHI605C) at 25 and $55{ }^{\circ} \mathrm{C}$, respectively.

\section{RESULTS AND DISCUSSION}

Ultrathin $\mathrm{ZnO}$ coatings can be deposited onto the surface of $\mathrm{LiMn}_{2} \mathrm{O}_{4}$ particles via ALD with high conformality and exquisite thickness control at the Angstrom or monolayer level. As shown in the schematic representation of $\mathrm{ZnO}$ ALD growth in Figure 1, $\mathrm{ZnO}$ film grows monolayer by monolayer due to the sequential and self-limiting surface reactions. The self-limiting aspect of ALD leads to excellent step coverage and conformal deposition on high aspect ratio structures. Another advantage of ALD approach is that it allows for direct deposition of $\mathrm{ZnO}$ on either as-prepared composite electrodes or individual electrode material particles, providing commercial feasibility for mass industrial production for lithium ion batteries. ${ }^{6,28,32}$

X-ray diffraction (XRD) pattern of $\mathrm{LiMn}_{2} \mathrm{O}_{4}$ particles coated with $6 \mathrm{ZnO}$ ALD layers (via 6 ALD growth cycles) is displayed in Figure 2 in comparison with that of bare $\mathrm{LiMn}_{2} \mathrm{O}_{4}$ particles. All distinct XRD peaks from the sample of $6 \mathrm{ZnO}$ ALD LMO $\left(\mathrm{LiMn}_{2} \mathrm{O}_{4}\right.$ particles coated with $6 \mathrm{ZnO}$ ALD layers) are well indexed to the spinel cubic structure of $\mathrm{LiMn}_{2} \mathrm{O}_{4}$ with a $\mathrm{F} 3 \mathrm{dm}$ space group (JCPDS, 35-0782). The $\mathrm{ZnO}$ phase is not detectable even when $50 \mathrm{ZnO}$ ALD layers are coated on pristine $\mathrm{LiMn}_{2} \mathrm{O}_{4}$ particles (Figure $\mathrm{S} 1$, Supporting Information), which can be ascribed to the amorphous phase and low weight ratio of $\mathrm{ZnO}^{7}$

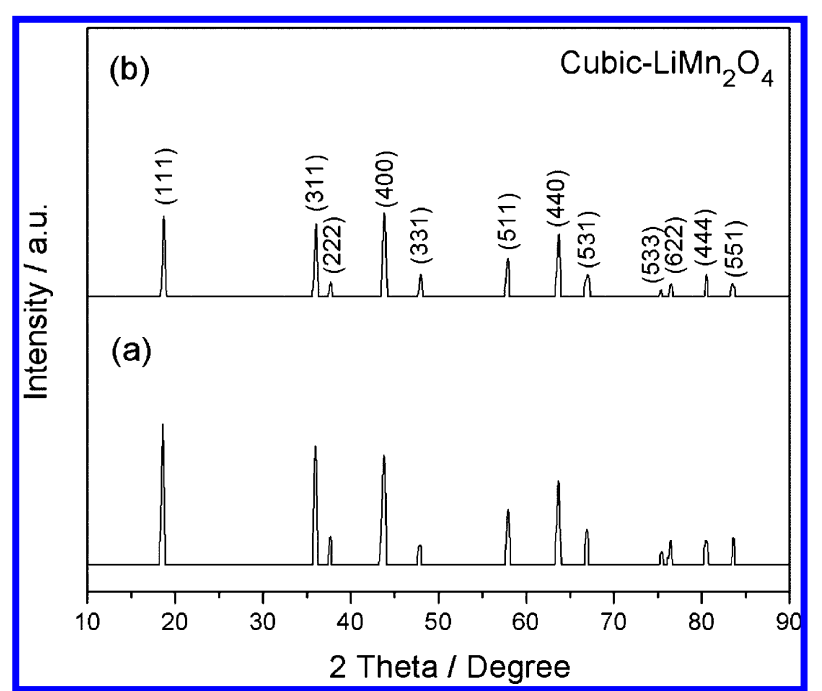

Figure 2. $\mathrm{XRD}$ patterns of (a) bare $\mathrm{LiMn}_{2} \mathrm{O}_{4}$ particles and (b) $\mathrm{LiMn}_{2} \mathrm{O}_{4}$ particles coated with $6 \mathrm{ZnO}$ ALD layers.

Figure 3 reveals the morphology and composition of $\mathrm{LiMn}_{2} \mathrm{O}_{4}$ particles before and after $\mathrm{ZnO}$ ALD coatings. Figure $3 a, b$ present SEM images of bare $\mathrm{LiMn}_{2} \mathrm{O}_{4}$ particles and $\mathrm{LiMn}_{2} \mathrm{O}_{4}$ particles coated with $6 \mathrm{ZnO}$ ALD layers, respectively. As can be seen from Figure $3 \mathrm{a}, \mathrm{LiMn}_{2} \mathrm{O}_{4}$ particles have an average particle size of $\sim 5 \mu \mathrm{m}$ with smooth polyhedron profile. Figure $3 \mathrm{~b}$ shows the shape and morphology of $\mathrm{LiMn}_{2} \mathrm{O}_{4}$ particles coated with $6 \mathrm{ZnO}$ ALD layers, which are almost identical to bare $\mathrm{LiMn}_{2} \mathrm{O}_{4}$ particles in Figure 3a. There is no visible difference in the SEM image after the $\mathrm{LiMn}_{2} \mathrm{O}_{4}$ particles are coated with $\mathrm{ZnO}$ ALD film, possibly because the ALD coating is ultrathin and highly conformal and thus preserves the 


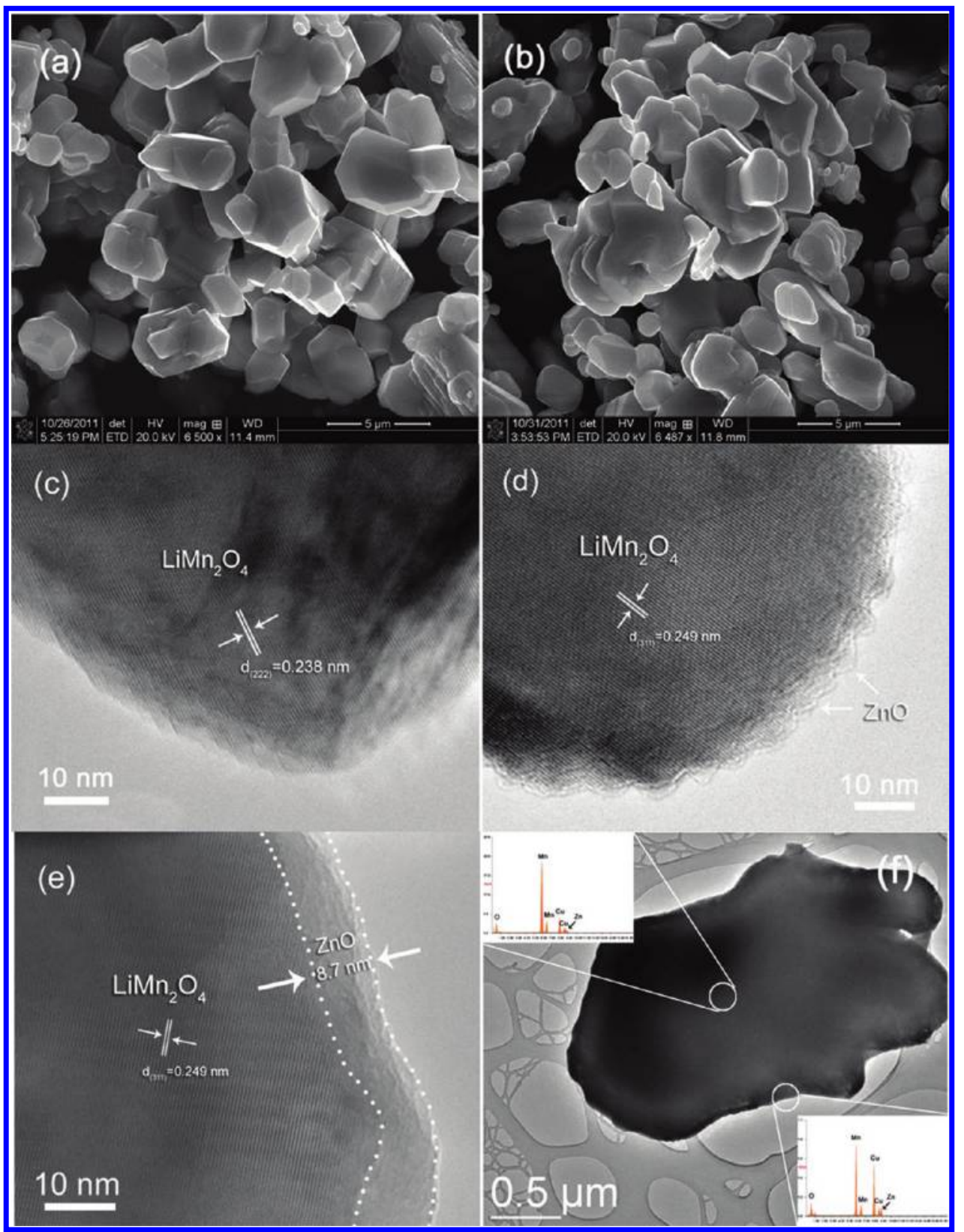

Figure 3. SEM images of (a) bare $\mathrm{LiMn}_{2} \mathrm{O}_{4}$ particle and (b) $\mathrm{LiMn}_{2} \mathrm{O}_{4}$ particle coated with $6 \mathrm{ZnO}$ ALD layers; HRTEM images of $(\mathrm{c})$ bare $\mathrm{LiMn}_{2} \mathrm{O}_{4}$ particle, (d) $\mathrm{LiMn}_{2} \mathrm{O}_{4}$ particle coated with $6 \mathrm{ZnO}$ ALD layers, and (e) $\mathrm{LiMn}_{2} \mathrm{O}_{4}$ particle coated with $50 \mathrm{ZnO}$ ALD layers; and (f) TEM image of $\mathrm{LiMn}_{2} \mathrm{O}_{4}$ particle coated with $50 \mathrm{ZnO}$ ALD layers (insets, EDS captured at the center and edge of this particle).

morphology of $\mathrm{LiMn}_{2} \mathrm{O}_{4}$ particles. Even when $\mathrm{LiMn}_{2} \mathrm{O}_{4}$ particles are coated with $50 \mathrm{ZnO} \mathrm{ALD}$ layers, the coated particles retain the same morphology and shape of bare particles as observed under SEM (Figure S2, Supporting Information), suggesting the high conformality of ALD coating.

To study the details of ALD coatings, high-resolution TEM (HRTEM) is used to examine uncoated and ALD-coated $\mathrm{LiMn}_{2} \mathrm{O}_{4}$ particles. Figure $3 \mathrm{c}, \mathrm{d}$ present HRTEM images of a bare $\mathrm{LiMn}_{2} \mathrm{O}_{4}$ particle and a $\mathrm{LiMn}_{2} \mathrm{O}_{4}$ particle coated with 6 $\mathrm{ZnO}$ ALD layers. It is noted that bare $\mathrm{LiMn}_{2} \mathrm{O}_{4}$ particle is crystalline, as lattice fringes are observed in Figure $3 \mathrm{c}$ with $d_{(222)}$ $=0.238 \mathrm{~nm}$, while TEM image of the $\mathrm{ZnO}$ coated $\mathrm{LiMn}_{2} \mathrm{O}_{4}$ (Figure $3 \mathrm{~d}$ ) reveals that a very thin and amorphous ALD coating fully and conformally enwraps around the crystalline $\mathrm{LiMn}_{2} \mathrm{O}_{4}$ particle. To obtain more information about ALD coatings, $\mathrm{LiMn}_{2} \mathrm{O}_{4}$ particles are coated with thicker $\mathrm{ZnO}$ ALD film (50 ALD layers using 50 ALD growth cycles) and are examined under HRTEM, as presented in Figure 3e,f. Figure 3e clearly shows that an amorphous and homogeneous ALD film is conformally coated on the crystalline $\mathrm{LiMn}_{2} \mathrm{O}_{4}$ particle. Thickness of the coating is estimated to $8.7 \mathrm{~nm}$, corresponding to an ALD growth rate of $1.7 \AA /$ cycle. In order to confirm the deposition of $\mathrm{ZnO}$ on the surface of $\mathrm{LiMn}_{2} \mathrm{O}_{4}$, energy dispersive $\mathrm{X}$-ray spectroscopy (EDS) is used to examine the compositions at the center and the edge of coated $\mathrm{LiMn}_{2} \mathrm{O}_{4}$, respectively, as shown in the inset graphs of Figure 3f. Both EDS spectra reveal the elements of $\mathrm{O}, \mathrm{Mn}, \mathrm{Zn}$, and $\mathrm{Cu}$. The $\mathrm{Cu}$ peaks are from the copper grid where the TEM sample is placed on. It is noted that the atomic percent of $\mathrm{Zn}$ on the edge is $10.9 \%$, larger than $7.1 \%$ in the center, confirming the formation of $\mathrm{ZnO}$ coating on the surface of $\mathrm{LiMn}_{2} \mathrm{O}_{4}$ particle. Therefore, from the SEM and TEM results in Figure 3, we can 


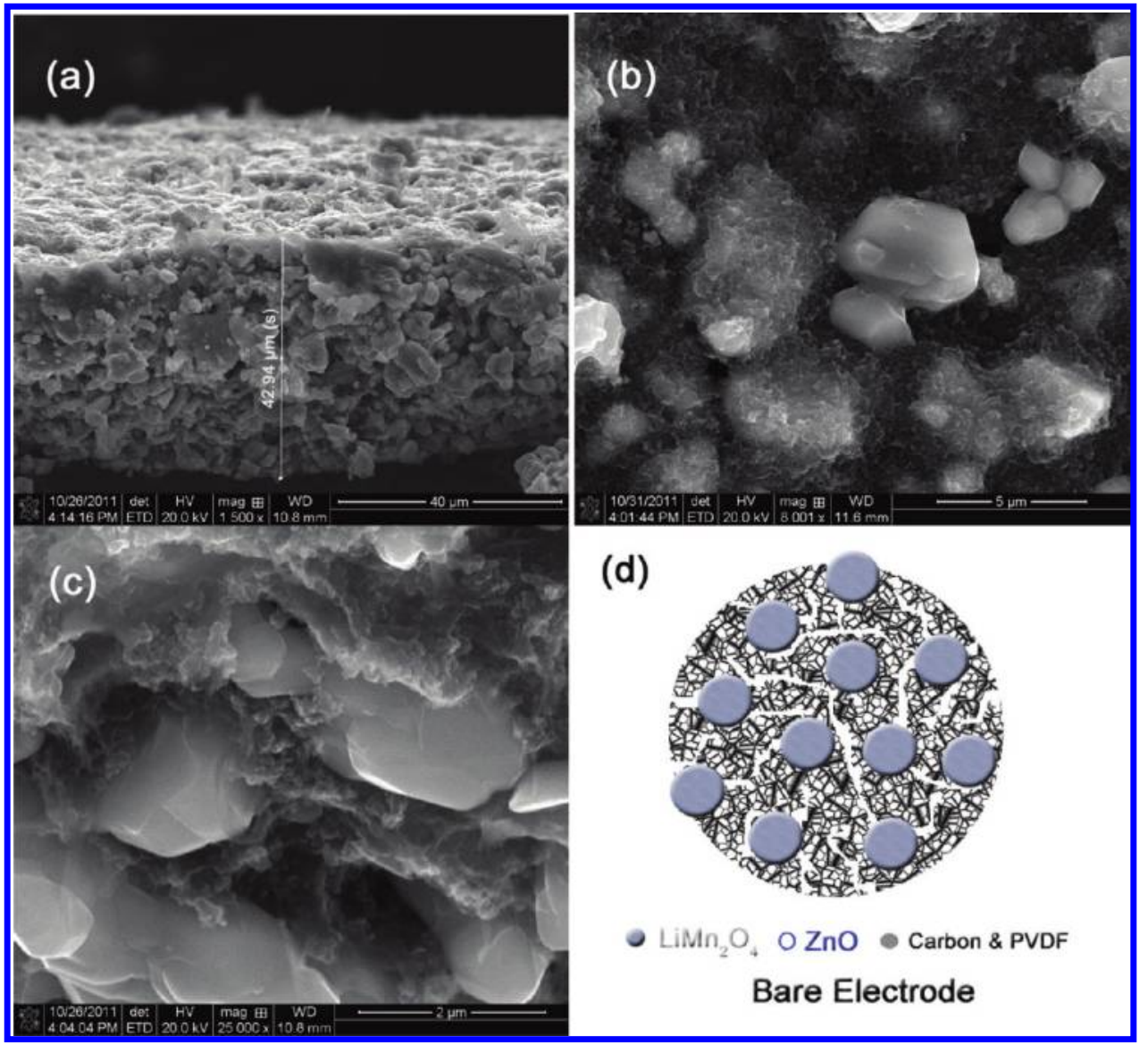

Figure 4. (a) Cross-section SEM image, (b) surface view, (c) enlarged cross-section SEM image, and (d) schematic representation of bare $\mathrm{LiMn}_{2} \mathrm{O}_{4}$ composite electrode.

conclude that $\mathrm{ZnO}$ ALD coatings are ultrathin, dense, uniform, highly conformal, and provide full coverage of $\mathrm{LiMn}_{2} \mathrm{O}_{4}$ particles.

Before integrating into lithium ion battery cells, $\mathrm{LiMn}_{2} \mathrm{O}_{4}$ cathode is fabricated by mixing $80 \% \mathrm{LiMn}_{2} \mathrm{O}_{4}$ particles, $10 \%$ acetylene black as conducting material, and $10 \%$ polyvinylidenefluoride (PVDF) as a binder. Figure $4 a-c$ show the SEM images of cross-section view, surface view, and enlarged crosssection view of $\mathrm{LiMn}_{2} \mathrm{O}_{4}$ cathode, respectively. The cathode shows an even thickness of $\sim 43 \mu \mathrm{m}$ (Figure 4a). As seen from the surface morphology (Figure $4 \mathrm{~b}$ ) and the cross-section profile of $\mathrm{LiMn}_{2} \mathrm{O}_{4}$ cathode (Figure 4c), $\mathrm{LiMn}_{2} \mathrm{O}_{4}$ particles are immersed in a porous network composed of smaller carbon and PVDF particles. Figure $4 \mathrm{~d}$ exhibits a schematic illustrating this morphology and structure of $\mathrm{LiMn}_{2} \mathrm{O}_{4}$ cathode.

We have prepared three types of $\mathrm{LiMn}_{2} \mathrm{O}_{4}$-based electrodes as shown in the schematics in Figure 5. One is a bare electrode consisting of bare $\mathrm{LiMn}_{2} \mathrm{O}_{4}$ particles, carbon, and PVDF, denoted by B-E. The second type of electrode is composed of ALD-coated $\mathrm{LiMn}_{2} \mathrm{O}_{4}$ particles, carbon and PVDF, denoted by ALD LMO-E. The third is obtained by depositing ALD coating onto the entire bare electrode, which is marked with ALD-E. Since ALD allows for the growth of conformal films even on substrates with complex surface geometries, ${ }^{6,32,35,36} \mathrm{ZnO}$ film will penetrate into the porous electrode, and coat onto both micrometer-sized $\mathrm{LiMn}_{2} \mathrm{O}_{4}$ particles and porous framework bridged by carbon and PVDF in the case of "ALD-E", as illustrated in the right picture of Figure $5 . \mathrm{LiMn}_{2} \mathrm{O}_{4}$ particles are partially covered by ALD coatings because $\mathrm{LiMn}_{2} \mathrm{O}_{4}$ particles

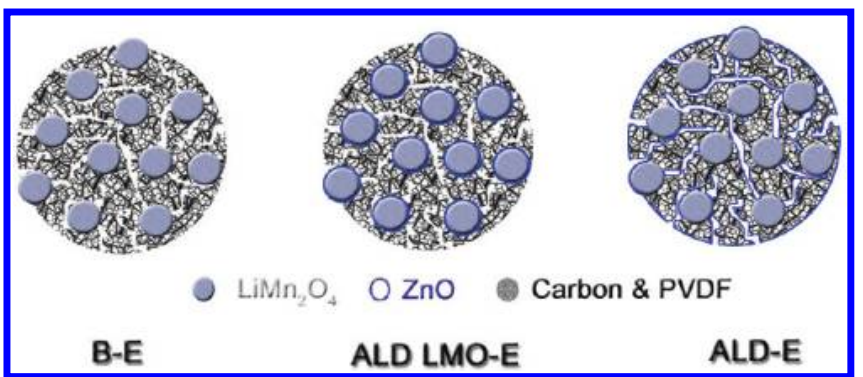

Figure 5. Schematic representations of bare $\mathrm{LiMn}_{2} \mathrm{O}_{4}$ composite electrode (left), electrode composed of ALD-coated $\mathrm{LiMn}_{2} \mathrm{O}_{4}$ particles and uncoated carbon/PVDF (center), and ALD-coated $\mathrm{LiMn}_{2} \mathrm{O}_{4}$ composite electrode (right).

are tightly enwrapped by carbon and PVDF network as shown in the cross-section SEM image of the electrode (Figure 4c). Therefore, in these three different electrodes, there are various interfaces between $\mathrm{LiMn}_{2} \mathrm{O}_{4}$ particles, ALD coatings, carbon and PVDF composites, and surrounding electrolyte, to affect electron transport and $\mathrm{Li}$ ion diffusion during delithiation and lithiation reactions, resulting in different electrochemical behaviors of these electrodes. It is noted that SEM images captured from an electrode composed of $\mathrm{LiMn}_{2} \mathrm{O}_{4}$ particles coated with $6 \mathrm{ZnO}$ ALD layers and uncoated carbon/PVDF network, $\mathrm{LiMn}_{2} \mathrm{O}_{4}$ composite electrode coated with $6 \mathrm{ZnO}$ ALD layers, and $\mathrm{LiMn}_{2} \mathrm{O}_{4}$ composite electrode coated with 50 $\mathrm{ZnO}$ ALD layers (Figure S3, Supporting Information) are all similar to the SEM image of bare $\mathrm{LiMn}_{2} \mathrm{O}_{4}$ composite 
electrode, indicating that $\mathrm{ZnO}$ ALD coatings on the composite electrodes are ultrathin, homogeneous, and highly conformal.

To confirm the formation of $\mathrm{ZnO}$ on the surface of $\mathrm{LiMn}_{2} \mathrm{O}_{4}$ particles and $\mathrm{LiMn}_{2} \mathrm{O}_{4}$ electrode, $\mathrm{X}$-ray photoelectron spectroscopy (XPS) is used to analyze the surface compositions of $\mathrm{LiMn}_{2} \mathrm{O}_{4}$ particles coated with $6 \mathrm{ZnO}$ ALD layers and $\mathrm{LiMn}_{2} \mathrm{O}_{4}$ composite electrode coated with $6 \mathrm{ZnO}$ ALD layers, respectively, as shown in Figure 6. Both spectra show the $\mathrm{Zn}$

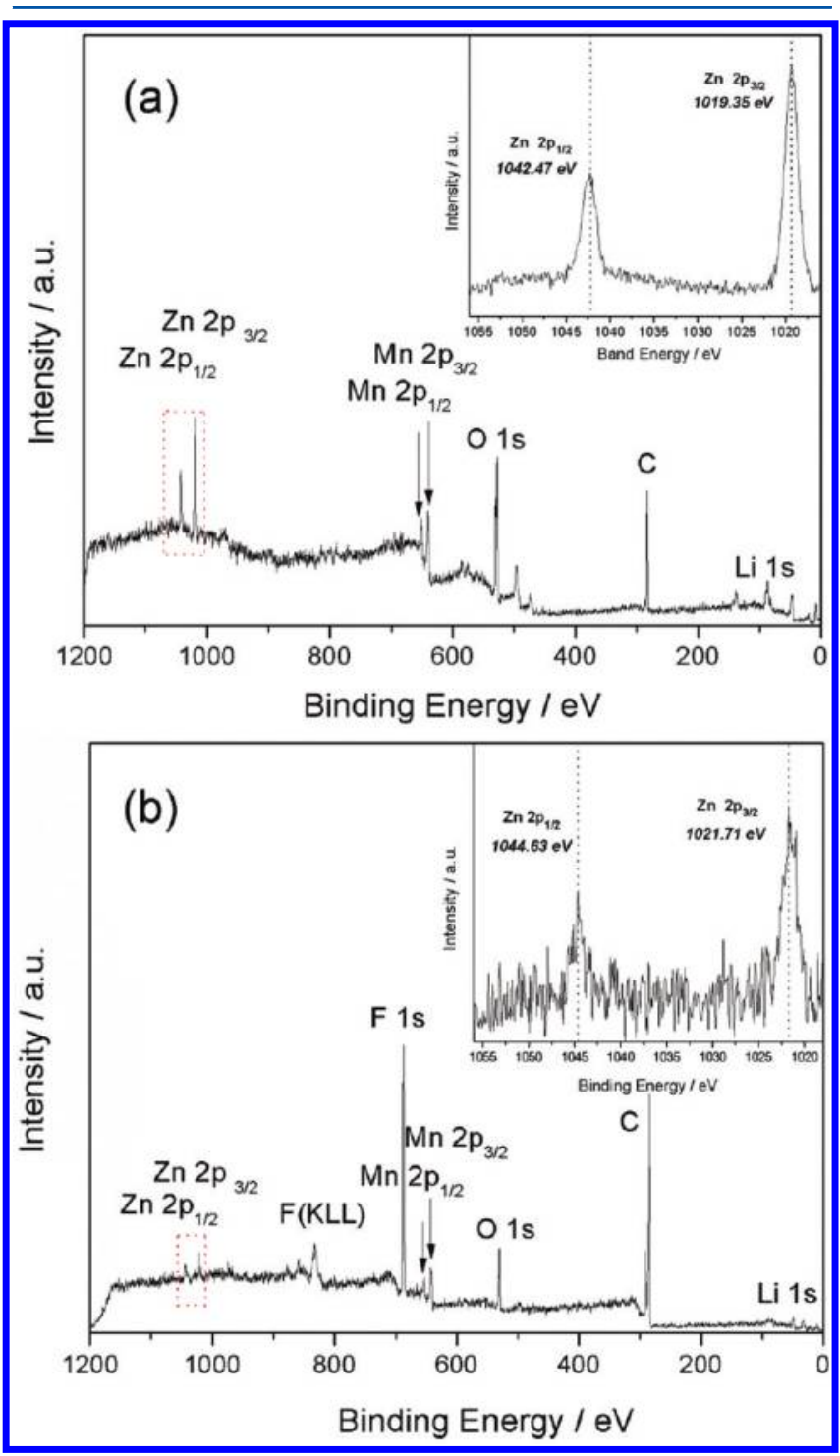

Figure 6. XPS spectra of (a) $\mathrm{LiMn}_{2} \mathrm{O}_{4}$ particles coated with $6 \mathrm{ZnO}$ ALD layers and (b) $\mathrm{LiMn}_{2} \mathrm{O}_{4}$ composite electrode coated with $6 \mathrm{ZnO}$ ALD layers.

$2 \mathrm{p}_{3 / 2}$ and $2 \mathrm{p}_{1 / 2}$ peaks from $\mathrm{ZnO}$, indicating the existence of $\mathrm{ZnO}$ on the surface of the samples. However, the binding energies of the $\mathrm{Zn} 2 \mathrm{p}_{3 / 2}$ and $2 \mathrm{p}_{1 / 2}$ in XPS spectrum of $6 \mathrm{ZnO}$ ALD LMO are 1019.4 and $1042.5 \mathrm{eV}$ (Figure 6a), respectively, shifting $\sim 2 \mathrm{eV}$ to the lower binding energy in comparison with the standard values of $\mathrm{ZnO}$ (1021.7 and $1044.7 \mathrm{eV}$ ) in NIST XPS Database, while the binding energies of $\mathrm{Zn} 2 \mathrm{p}_{3 / 2}$ of 1021.7 $\mathrm{eV}$ and $2 \mathrm{p}_{1 / 2}$ of $1044.6 \mathrm{eV}$ observed for $6 \mathrm{ZnO}$ ALD-E sample in Figure $6 \mathrm{~b}$ are consistent with standard values of $\mathrm{ZnO}$. This difference is possibly due to different chemical and bonding environments of $\mathrm{ZnO}$ ALD coatings on $\mathrm{LiMn}_{2} \mathrm{O}_{4}$ particles and
$\mathrm{LiMn}_{2} \mathrm{O}_{4}$ composite electrode. In ALD coating, substrate material and $\mathrm{ZnO}$ coating film are bridged by the chemical bond, oxygen bond (substrate- $\mathrm{O}-\mathrm{ZnO}$ ) illustrated in Figure 1. In $6 \mathrm{ZnO} \mathrm{ALD}-\mathrm{E}$, the $\mathrm{ZnO}$ is mainly deposited on conductive carbon due to the hydrophobic selection property of PVDF to hydroxyl groups (Figure 5), ${ }^{35}$ while in $6 \mathrm{ZnO}$ ALD $\mathrm{LMO}$, the $\mathrm{ZnO}$ is grown tightly on $\mathrm{LiMn}_{2} \mathrm{O}_{4}$ particles. We speculate that the different electronic distribution and polarity of substrate materials $\left(\mathrm{LiMn}_{2} \mathrm{O}_{4}\right.$ and carbon) influence the chemical environment of $\mathrm{ZnO}$ coating via oxygen bond, contributing to the peak shift of $\mathrm{Zn} 2 \mathrm{p}$ in $6 \mathrm{ZnO}$ ALD LMO.

The three types of electrodes shown in Figure 5 are then integrated into CR2032-type coin cells with lithium as anode for electrochemical testing. Electrochemical measurements are performed for bare electrode (B-E), electrodes coated with ALD films of various thicknesses (2, 6, and $10 \mathrm{ZnO} \mathrm{ALD}$ layers) (samples denoted by $2 \mathrm{ZnO}$ ALD-E, $6 \mathrm{ZnO}$ ALD-E, and $10 \mathrm{ZnO} A L D-E)$, and electrode composed of $\mathrm{LiMn}_{2} \mathrm{O}_{4}$ particles coated with 2, 6, and $10 \mathrm{ZnO}$ ALD layers and carbon/PVDF (marked with $2 \mathrm{ZnO}$ ALD LMO-E, $6 \mathrm{ZnO}$ ALD LMO-E, and $10 \mathrm{ZnO}$ ALD LMO-E). Figure 7 summarizes cycling performances of these electrodes cycled at a current density of $120 \mathrm{~mA} / \mathrm{g}$ in a voltage range of $3.4-4.5 \mathrm{~V}$ at 25 and $55^{\circ} \mathrm{C}$. All ALD-modified $\mathrm{LiMn}_{2} \mathrm{O}_{4}$ electrodes exhibit higher final capacities than bare cathode after 100 electrochemical cycles. $\mathrm{ZnO}$ coatings have been reported as the most effective $\mathrm{HF}$ scavenger among $\mathrm{Al}_{2} \mathrm{O}_{3}, \mathrm{ZrO}_{2}$, and $\mathrm{SnO}_{2}$ to protect $\mathrm{LiMn}_{2} \mathrm{O}_{4}$ particles from the detrimental $\mathrm{Mn}$ dissolution. ${ }^{15}$ The $\mathrm{ZnO}$ thin film can serve as an amorphous interphase between electrode and electrolyte to prevent from electrolyte decomposition and formation of the insulating solid electrolyte interphase (SEI) on the surface of working electrode. ${ }^{2,28}$

It has been estimated from the TEM results in Figure 3 that the growth rate of this $\mathrm{ZnO}$ ALD is $1.7 \AA$ /cycle, and thus, one ALD layer is $1.7 \AA$ thick. As shown in Figure 7a,c, the electrode coated with $6 \mathrm{ZnO}$ ALD layers (1.02 nm thick) delivers the best cycling performance and the highest final capacity among the electrodes coated with $\mathrm{ZnO}$ ALD films of different thicknesses, either at 25 or $55^{\circ} \mathrm{C}$. This $6 \mathrm{ZnO}$ ALD-E delivers a final capacity of $44.5 \mathrm{mAh} / \mathrm{g}$ after 100 electrochemical cycles at $1 \mathrm{C}$ at $55^{\circ} \mathrm{C}$, much higher than the final capacity of 27.0 $\mathrm{mAh} / \mathrm{g}$ delivered by bare electrode at $55{ }^{\circ} \mathrm{C}$. When $\mathrm{ZnO}$ is coated on $\mathrm{LiMn}_{2} \mathrm{O}_{4}$ particles as shown in Figure $7 \mathrm{~b}, \mathrm{~d}, 6 \mathrm{ZnO}$ ALD layers are also the optimal thickness for the best cycling performance either at room temperature or elevated temperature. When the ALD coating is too thin, it is not sufficient to scavenge the harmful HF generated during electrochemical cycling and thus the effect of surface coating to enhance the performance of the electrode is less distinct, as observed for electrodes coated with 2 ALD layers. However, an overly thick $\mathrm{ZnO}$ ALD coating will slow down the diffusion of lithium ions at the interface between electrode and electrolyte and will thus reduce the capacities of the electrode, ${ }^{27}$ as observed for electrodes coated with 10 ALD layers. Therefore, it is feasible to accurately tune the thickness of ALD coatings for ultimate optimization of lithium ion battery performances because ALD offers precise thickness control at the atomic level. In addition, the protective effect of $\mathrm{ZnO} A L D$ coatings to the $\mathrm{LiMn}_{2} \mathrm{O}_{4}$ electrode is even more obvious when the electrode is cycled at elevated temperature than cycled at room temperature, by comparing Figure $7 \mathrm{a}, \mathrm{c}$ for $\mathrm{ZnO}$ coated electrodes as well as Figure $7 \mathrm{~b}, \mathrm{~d}$ for $\mathrm{ZnO}$ modified $\mathrm{LiMn}_{2} \mathrm{O}_{4}$ particles. In comparison with ALD oxide coatings on different nanosized 

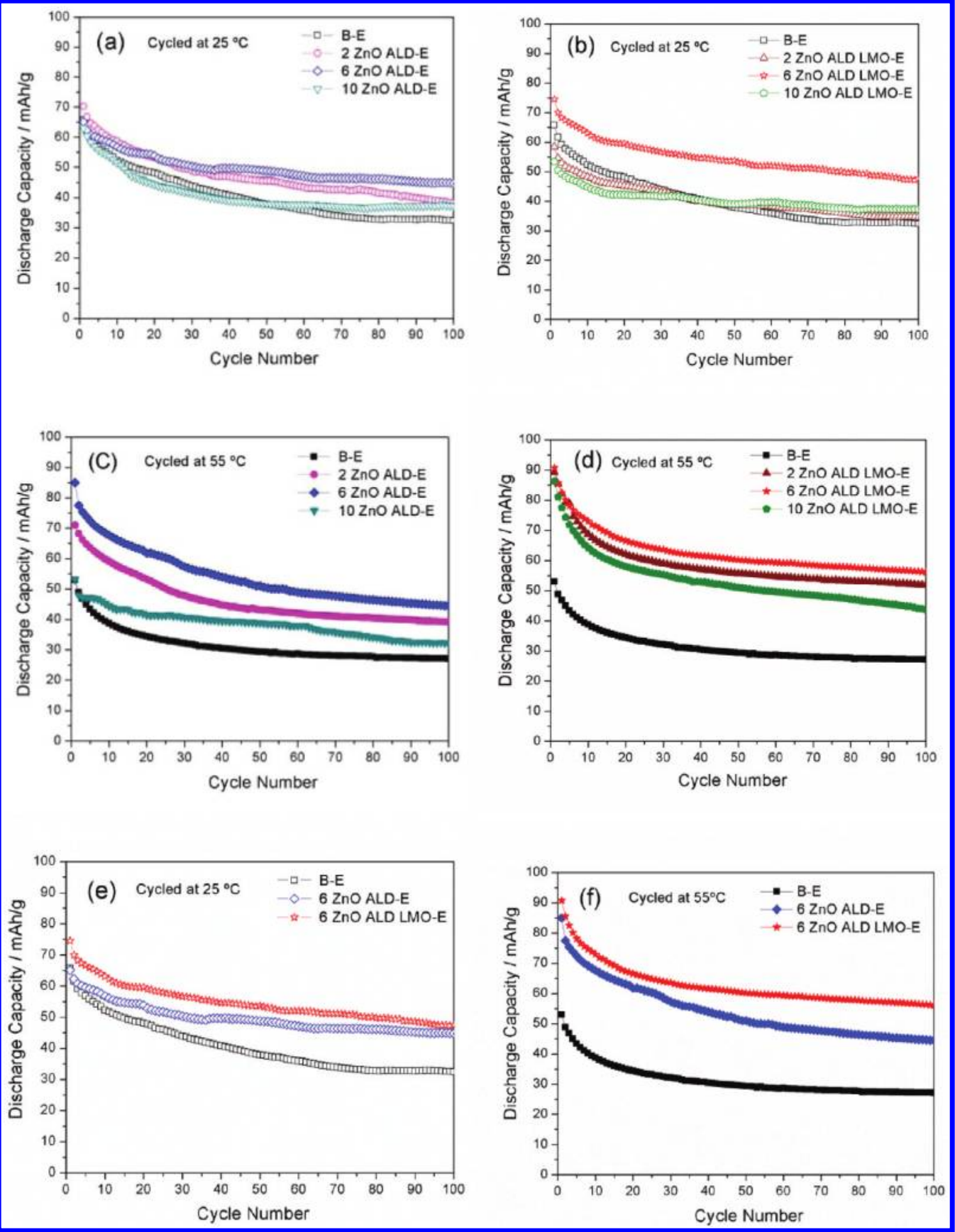

Figure 7. Cycling performances of various electrodes at a current density of $120 \mathrm{~mA} / \mathrm{g}$ in a voltage range of $3.4-4.5 \mathrm{~V}$ vs. Li: (a,b,e) cycled at $25^{\circ} \mathrm{C}$; $(\mathrm{c}, \mathrm{d}, \mathrm{f})$ cycled at $55^{\circ} \mathrm{C}$. B-E, bare $\mathrm{LiMn}_{2} \mathrm{O}_{4}$ composite electrode; $n \mathrm{ZnO}$ ALD-E, $\mathrm{LiMn}_{2} \mathrm{O}_{4}$ composite electrode coated with $n$ ZnO ALD layers; $n$ $\mathrm{ZnO}$ ALD LMO-E, electrode composed of $\mathrm{LiMn}_{2} \mathrm{O}_{4}$ particles coated with $n \mathrm{ZnO}$ ALD layers and uncoated carbon/PVDF network.

cathode materials, such as $\mathrm{LiCoO}_{2}{ }^{27,35,36}$ and $\mathrm{Li}$ $\mathrm{Ni}_{1 / 3} \mathrm{Mn}_{1 / 3} \mathrm{Co}_{1 / 3} \mathrm{O}_{2}$, ${ }^{34}$ the initial capacity drops during the first several cycles in this work are probably due to the micrometer-sized $\mathrm{LiMn}_{2} \mathrm{O}_{4}$ particles, which have an average size of $5 \mu \mathrm{m}$, inevitable $\mathrm{Mn}$ dissolution in $\mathrm{LiMn}_{2} \mathrm{O}_{4}$-based cathodes and the resultant electrochemical polarization of the cathodes at a relatively high current density of approximate $1 \mathrm{C}$. It is found in our other work that there is much less distinct initial capacity degradation for nanosized $\mathrm{LiMn}_{2} \mathrm{O}_{4}$ and this work has been submitted elsewhere. There is also ongoing work in our laboratory to alleviate the initial capacity drops via heat treatments of microsized $\mathrm{LiMn}_{2} \mathrm{O}_{4}$. Furthermore, at the elevated temperature, $\mathrm{LiMn}_{2} \mathrm{O}_{4}$ suffers from faster capacity fading because high temperature accelerates side reactions and electrolyte decomposition in battery cells, which will induce more severe $\mathrm{Mn}$ dissolution. ${ }^{42}$

Figure $7 \mathrm{a}-\mathrm{d}$ indicate that $\mathrm{ZnO}$ coating on $\mathrm{LiMn}_{2} \mathrm{O}_{4}$ particles is more sensitive for improved electrochemical performance than $\mathrm{ZnO}$ depositing on composite electrodes. Figure $7 \mathrm{e}, \mathrm{f}$ present cycling performances of bare electrode (B-E), $\mathrm{LiMn}_{2} \mathrm{O}_{4}$ electrode coated with $6 \mathrm{ZnO}$ ALD layers (6 ZnO ALD-E), and the electrode composed of $\mathrm{LiMn}_{2} \mathrm{O}_{4}$ particles coated with 6 $\mathrm{ZnO}$ ALD layers and carbon/PVDF (6 ZnO ALD LMO-E) at 25 and $55{ }^{\circ} \mathrm{C}$, respectively. Differences in the morphology and structure of these three electrodes are illustrated in Figure 5. It is interesting to note that $6 \mathrm{ZnO}$ ALD LMO-E shows even 
better cycling performance and higher capacities than $6 \mathrm{ZnO}$ ALD-E. As shown in Figure 7e, $6 \mathrm{ZnO}$ ALD LMO-E delivers an initial discharge capacity of $74.6 \mathrm{mAh} / \mathrm{g}$ at $25^{\circ} \mathrm{C}$, higher than the initial capacities of $65.1 \mathrm{mAh} / \mathrm{g}$ from $6 \mathrm{ZnO}$ ALD-E and $65.7 \mathrm{mAh} / \mathrm{g}$ from B-E at $25{ }^{\circ} \mathrm{C}$. The increased capacity of 6 $\mathrm{ZnO}$ ALD LMO-E can be attributed to the following factors: (1) $\mathrm{ZnO}$ film is fully coated onto $\mathrm{LiMn}_{2} \mathrm{O}_{4}$ particles in $6 \mathrm{ZnO}$ ALD LMO-E, while $\mathrm{ZnO}$ film is partially coated onto $\mathrm{LiMn}_{2} \mathrm{O}_{4}$ particles within the $\mathrm{ZnO}$ coated carbon/PVDF network in 6 $\mathrm{ZnO}$ ALD-E as shown in Figure 5; this difference in ZnO ALD coverage of $\mathrm{LiMn}_{2} \mathrm{O}_{4}$ particles may contribute to the higher capacities of $6 \mathrm{ZnO}$ ALD LMO-E than $6 \mathrm{ZnO}$ ALD-E; (2) the semiconducting $\mathrm{ZnO}$ film can average the distribution of electrons and lithium ions around the whole $\mathrm{LiMn}_{2} \mathrm{O}_{4}$ surface to take full advantage of the active sites for $\mathrm{Li}^{+}$insertion and extraction; the polarization from the concentration difference of $\mathrm{Li}^{+}$and electrons can be reduced in the working electrode; (3) the conformal and dense $\mathrm{ZnO}$ coatings, as shown in Figures 1 and $3 \mathrm{~d}$, can serve as a solid framework to restrain the phase transition of $\mathrm{LiMn}_{2} \mathrm{O}_{4}$ from cubic to tetragonal structure and thus to prevent the harmful Jane-Taller effect; (4) dissolution of $\mathrm{Mn}$ ions into the internal structure of carbon and PVDF network can be reduced due to the complete $\mathrm{ZnO}$ coverage on $\mathrm{LiMn}_{2} \mathrm{O}_{4}$ particles in $6 \mathrm{ZnO}$ ALD LMO-E, while $\mathrm{ZnO}$ coverage on $\mathrm{LiMn}_{2} \mathrm{O}_{4}$ particles is partial in $6 \mathrm{ZnO}$ ALD-E (Figure 5). Therefore, $6 \mathrm{ZnO}$ ALD LMO-E delivers the highest discharge capacity. However, the capacity retention of $6 \mathrm{ZnO}$ ALD LMO$\mathrm{E}$ after 100 cycles is slightly worse than that of $6 \mathrm{ZnO}$ ALD-E, possibly due to less $\mathrm{ZnO}$ content in $6 \mathrm{ZnO}$ ALD LMO-E to rapidly consume the $\mathrm{HF}$. As shown in Figure 5, the composite electrode can be coated with more $\mathrm{ZnO}$ than $\mathrm{LiMn}_{2} \mathrm{O}_{4}$ particles because the electrode composed of micrometer-sized $\mathrm{LiMn}_{2} \mathrm{O}_{4}$ particles buried in porous carbon/PVDF network has larger surface area than micrometer-sized $\mathrm{LiMn}_{2} \mathrm{O}_{4}$ particles.

At elevated temperature, $\mathrm{LiMn}_{2} \mathrm{O}_{4}$ electrode will suffer from faster capacity fading because high temperature accelerates chemical kinetics in the battery cell and aggravates negative factors in terms of $\mathrm{Mn}$ dissolution, phase transition, and electrolyte decomposition. ${ }^{7}$ However, higher temperature also leads to enhanced electrical conductivity and faster lithium ion diffusion in $\mathrm{LiMn}_{2} \mathrm{O}_{4}$ electrode, which can contribute to less polarization and subsequently improved energy and powder densities of $\mathrm{LiMn}_{2} \mathrm{O}_{4}$. Figure $7 \mathrm{c}, \mathrm{d}$,f illuminates this competitive relationship between such negative and positive influences on different composite electrodes. Bare electrode displays more severe capacity loss at $55{ }^{\circ} \mathrm{C}$ compared to that at $25{ }^{\circ} \mathrm{C}$, as shown in Figure 7. The capacity fading of B-E is mainly ascribed to the intensified Mn dissolution, which becomes the predominant factor at elevated temperature without any protective surface coatings on the composite electrode. ${ }^{7,16} 2$ $\mathrm{ZnO}$ ALD-E exhibits similar electrochemical behaviors at 55 and $25{ }^{\circ} \mathrm{C}$ without much change in cycleability when the sample is subjected to higher temperature, indicating that the ultrathin $\mathrm{ZnO}$ coating ( 2 ALD layers, $0.34 \mathrm{~nm}$ thick) can adequately impede $\mathrm{Mn}$ dissolution at elevated temperature. The effect of ALD coatings to enhance performance of $\mathrm{LiMn}_{2} \mathrm{O}_{4}$ at higher temperature is more phenomenal when thickness of ALD coatings is optimized to be 6 ALD layers $(1.02 \mathrm{~nm}) .6 \mathrm{ZnO}$ ALD-E shows a higher initial capacity (84.9 $\mathrm{mAh} / \mathrm{g}$ ) at $55^{\circ} \mathrm{C}$ than that at $25^{\circ} \mathrm{C}$. It is speculated that, when $\mathrm{Mn}$ dissolution at elevated temperature is effectively restrained by $6 \mathrm{ZnO} \mathrm{ALD}$ layers as it works at room temperature, the enhanced conductivity and $\mathrm{Li}$ ion diffusion rate in the electrode at higher temperature becomes the leading beneficial factor resulting in increased capacity. In the case of $10 \mathrm{ZnO}$ ALD-E, the initial capacity at $55{ }^{\circ} \mathrm{C}$ is lower than that at $25^{\circ} \mathrm{C}$ because an overly thick $\mathrm{ZnO}$ coating may slow down $\mathrm{Li}^{+}$diffusion at elevated temperature, ${ }^{16,27}$ though this sample shows very good capacity retention after 100 electrochemical cycles. After 100 electrochemical cycles at $55{ }^{\circ} \mathrm{C}$, the obvious existence of residual $\mathrm{ZnO}$ coating in $10 \mathrm{ZnO} \mathrm{ALD}-\mathrm{E}$ is validated by XPS analysis of $\mathrm{Zn} 2 \mathrm{p}$ peaks in Figure S4a, Supporting Information. The apparently lower $\mathrm{Zn} 2 \mathrm{p}$ peaks can be observed from $6 \mathrm{ZnO}$ ALD-E after 100 electrochemical cycles at $55{ }^{\circ} \mathrm{C}$ (Figure S4b, Supporting Information) in comparison with that measured from the primary electrode coated with $6 \mathrm{ZnO}$ ALD layers before cycling (Figure $6 \mathrm{~b}$ ), indicating that $6 \mathrm{ZnO}$ ALD layers can be considered as the critical coating thickness to completely neutralize the HF but not influence the lithium ion diffusivity. In summary, a surface coating composed of $6 \mathrm{ZnO}$ ALD layers (1.02 nm thick) has optimal thickness for enhancing the performance of $\mathrm{LiMn}_{2} \mathrm{O}_{4}$ electrode, and the positive effect of this coating is more distinct at elevated temperature. Furthermore, when this optimal $6 \mathrm{ZnO}$ ALD layers are coated onto $\mathrm{LiMn}_{2} \mathrm{O}_{4}$ particles instead of the entire composite electrode, the effect of this coating to enhance the performance of electrode at elevated temperature is even more phenomenal. The sample $6 \mathrm{ZnO}$ ALD LMO-E delivers an initial capacity of $90.8 \mathrm{mAh} / \mathrm{g}$ at $55^{\circ} \mathrm{C}$, which is higher than that of $6 \mathrm{ZnO}$ ALD$\mathrm{E}(84.9 \mathrm{mAh} / \mathrm{g})$ and 1.7 times larger than that of B-E (52.9 $\mathrm{mAh} / \mathrm{g}$ ) at $55^{\circ} \mathrm{C} .6 \mathrm{ZnO}$ ALD LMO-E also delivers the highest final capacity of $56.1 \mathrm{mAh} / \mathrm{g}$ at $55{ }^{\circ} \mathrm{C}$, higher than that of 6 $\mathrm{ZnO}$ ALD-E $(44.5 \mathrm{mAh} / \mathrm{g})$ and that of B-E $(27.0 \mathrm{mAh} / \mathrm{g})$ at 55 ${ }^{\circ} \mathrm{C}$. Moreover, under a low current density of $0.1 \mathrm{C}, 6 \mathrm{ZnO}$ ALD LMO-E delivers a high initial discharge capacity of 119.1 $\mathrm{mAh} / \mathrm{g}$ at $55{ }^{\circ} \mathrm{C}$ (Figure S5, Supporting Information), confirming its outstanding electrochemical performance at elevated temperature.

In order to further evaluate the effect of $\mathrm{ZnO}$ ALD coating on $\mathrm{LiMn}_{2} \mathrm{O}_{4}$ particles at elevated temperature, the cyclic voltammetric $(\mathrm{CV})$ measurements of $6 \mathrm{ZnO}$ ALD LMO-E are carried out at a scan rate of $0.1 \mathrm{mV} / \mathrm{s}$ between 3.4 and $4.5 \mathrm{~V}$ vs. $\mathrm{Li}$, at 25 and $55^{\circ} \mathrm{C}$, respectively, as shown in Figure 8a. It can be seen that the anodic peak current located at $4.18 \mathrm{~V}$ at $55^{\circ} \mathrm{C}$ is larger than the peak at $4.17 \mathrm{~V}$ at $25^{\circ} \mathrm{C}$, indicating that more lithium ions can be extracted from the $\mathrm{LiMn}_{2} \mathrm{O}_{4}$ structure due to the enhanced electrical conductivity from $3.82 \times 10^{-6}(25$ $\left.{ }^{\circ} \mathrm{C}\right)$ to $3.04 \times 10^{-5} \mathrm{~S} / \mathrm{cm}\left(55^{\circ} \mathrm{C}\right)$ of $6 \mathrm{ZnO}$ ALD LMO-E when it is subjected to elevated temperature. In the corresponding reduction cycle, the cathodic peak current at a high voltage of $4.06 \mathrm{~V}$ at $55{ }^{\circ} \mathrm{C}$ is also much higher than that at $4.08 \mathrm{~V}$ at 25 ${ }^{\circ} \mathrm{C}$, suggesting more intercalation of lithium ions into the host $\mathrm{LiMn}_{2} \mathrm{O}_{4}$ at $55{ }^{\circ} \mathrm{C}$. It should be noted that the improved conductivity and lithium ion diffusion rate at higher temperature stimulate the activity of lithium ions in the high voltage sites, resulting in improved specific capacity. The distinct peak at $4.5 \mathrm{~V}$ at $55^{\circ} \mathrm{C}$ indicates that decomposition of the electrolyte derived by the higher oxidation of $\mathrm{Mn}^{4+}$ due to the deep delithiation reaction is accelerated at elevated temperature. Figure $8 \mathrm{~b}$ exhibits charge/discharge profiles of $6 \mathrm{ZnO}$ ALD LMO-E from different electrochemical cycles at 25 and $55{ }^{\circ} \mathrm{C}$. As for the second cycle at $55{ }^{\circ} \mathrm{C}$, the charge curve presents two potential plateaus located at 4.03 and $4.16 \mathrm{~V}$, and the corresponding discharge curve displays plateaus at 4.08 and $3.95 \mathrm{~V}$, consistent with the CV curve. In contrast, the two pairs of weak voltage plateaus in charge and discharge curves at 25 

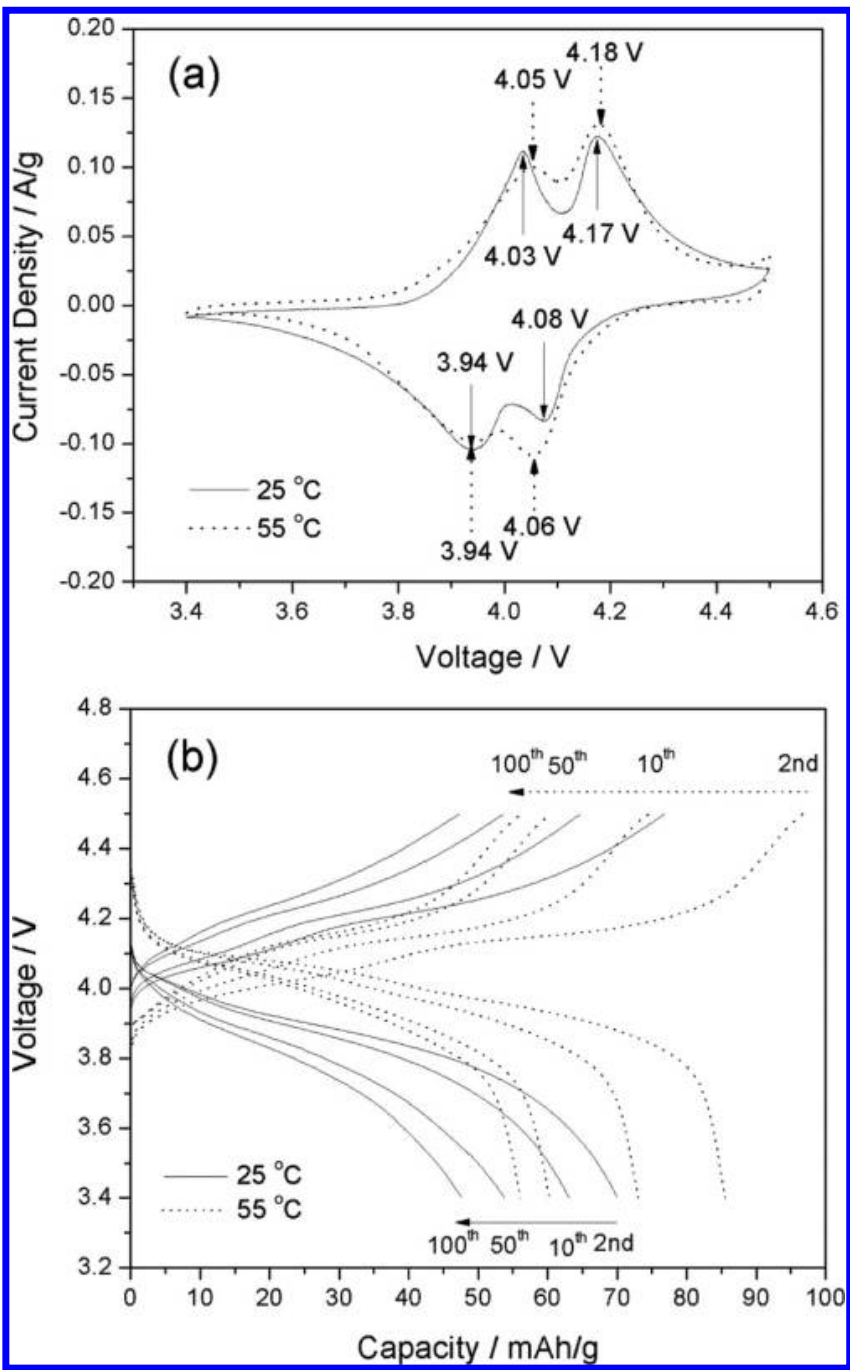

Figure 8. Electrochemical performances of the electrode composed of $\mathrm{LiMn}_{2} \mathrm{O}_{4}$ particles coated with $6 \mathrm{ZnO}$ ALD layers and carbon/PVDF network (6 ZnO ALD LMO-E): (a) CV curves at a scan rate of 0.1 $\mathrm{mV} / \mathrm{s}$ at 25 and $55^{\circ} \mathrm{C}$ and (b) charge/discharge curves from different electrochemical cycles at a current density of $120 \mathrm{mAh} / \mathrm{g}$ in a voltage range of $3.4-4.5 \mathrm{~V}$ vs. $\mathrm{Li}$ at 25 and $55^{\circ} \mathrm{C}$.

${ }^{\circ} \mathrm{C}$ are not well-matched with the redox peaks in the $\mathrm{CV}$ curve. The increased polarization can be attributed to the low conductivity of the working electrode and the usage of high current density in charge/discharge reactions at $25^{\circ} \mathrm{C}$, whereas the $\mathrm{CV}$ measurement was performed at a slow scan rate. The extended high-voltage plateaus can be clearly observed in the charge/discharge curves at $55{ }^{\circ} \mathrm{C}$ at the second, fifth, 50th, and 100th electrochemical cycles compared to those of charge/ discharge curves at $25{ }^{\circ} \mathrm{C}$. The enhanced mobility of lithium ions at high voltage at increased temperature thus contributes to the considerably improved capacity of the $6 \mathrm{ZnO} \mathrm{ALD}$ LMO-E at $55^{\circ} \mathrm{C}$.

\section{CONCLUSIONS}

We have deposited ultrathin and highly conformal $\mathrm{ZnO}$ coatings (as thin as $0.34-1.7 \mathrm{~nm}$ ) onto $\mathrm{LiMn}_{2} \mathrm{O}_{4}$ by using the atomic layer deposition method, for enhanced electrochemical performances of electrode materials. Thickness of $\mathrm{ZnO}$ ALD coatings can be tuned and precisely controlled by varying ALD growth cycles, with a growth rate of $1.7 \AA$ per cycle in this study. $\mathrm{ZnO}$ ALD coatings are deposited either onto the entire $\mathrm{LiMn}_{2} \mathrm{O}_{4}$ composite electrode or individual $\mathrm{LiMn}_{2} \mathrm{O}_{4}$ particles. All the ALD-modified electrodes demonstrate enhanced cycleability compared to bare electrodes at both 25 and $55^{\circ} \mathrm{C}$. Among electrodes coated with ALD films of different thicknesses, $\mathrm{LiMn}_{2} \mathrm{O}_{4}$ electrode coated with $6 \mathrm{ZnO}$ ALD layers ( $1.02 \mathrm{~nm}$ thick) shows the best cycling performance, demonstrating that it is facile to accurately tune the thickness of ALD coatings and thus optimize the electrochemical performances of ALD-modified electrodes simply via varying ALD growth cycles. Furthermore, the electrode composed of $\mathrm{LiMn}_{2} \mathrm{O}_{4}$ particles coated with $6 \mathrm{ZnO}$ ALD layers and uncoated carbon/PVDF network shows even better electrochemical performances than the $\mathrm{LiMn}_{2} \mathrm{O}_{4}$ composite electrode coated with $6 \mathrm{ZnO}$ ALD layers at both 25 and $55^{\circ} \mathrm{C}$, and the effect of $\mathrm{ZnO}$ ALD coatings is more phenomenal at the elevated temperature. The electrode composed of $\mathrm{LiMn}_{2} \mathrm{O}_{4}$ particles coated with $6 \mathrm{ZnO}$ ALD layers delivers the highest final capacity of $56.1 \mathrm{mAh} / \mathrm{g}$ after 100 electrochemical cycles at $1 \mathrm{C}$ at $55^{\circ} \mathrm{C}$, much higher than the final capcity of $27.0 \mathrm{mAh} / \mathrm{g}$ delivered by bare electrode at $55{ }^{\circ} \mathrm{C}$, showing that the effect of $\mathrm{ZnO} \mathrm{ALD}$ coatings to enhance the electrochemical performance of $\mathrm{LiMn}_{2} \mathrm{O}_{4}$ is more phenomenal at elevated temperature. The ultrathin and high-quality $\mathrm{ZnO}$ ALD coating can effectively alleviate dissolution of manganese ions into the electrolyte by scavenging $\mathrm{HF}$ and retards the electrolyte decomposition by isolating $\mathrm{LiMn}_{2} \mathrm{O}_{4}$ from the electrolyte. Lastly, the methods presented in this study can be generalized to other cathode materials and other coatings as long as the coatings can be fabricated via ALD. For example, ALD surface coatings will be used to improve electrochemical performances of high-capacity cathodes such as lithium-rich layered oxides $\mathrm{Li}[\mathrm{Li}, \mathrm{Mn}, \mathrm{Ni}, \mathrm{Co}]$ $\mathrm{O}_{2}$ in our laboratory.

\section{ASSOCIATED CONTENT}

\section{S Supporting Information}

XRD pattern and SEM image of $\mathrm{LiMn}_{2} \mathrm{O}_{4}$ particles coated with $50 \mathrm{ZnO}$ ALD layers; SEM images of electrode composed of $\mathrm{LiMn}_{2} \mathrm{O}_{4}$ particles coated with $6 \mathrm{ZnO}$ ALD layers and carbon/ PVDF network, composite electrode coated with $6 \mathrm{ZnO}$ ALD layers, and composite electrode coated with $50 \mathrm{ZnO} \mathrm{ALD}$ layers; XPS spectra of $\mathrm{Zn} 2 \mathrm{p}$ from $\mathrm{LiMn}_{2} \mathrm{O}_{4}$ composite electrodes coated with 6 and $10 \mathrm{ZnO}$ ALD layers after 100 cycles at $55{ }^{\circ} \mathrm{C}$; cycling performance of the electrode composed of $\mathrm{LiMn}_{2} \mathrm{O}_{4}$ particles coated with $6 \mathrm{ZnO}$ ALD layers and carbon/PVDF network at $0.1 \mathrm{C}$ at elevated temperature (55 ${ }^{\circ} \mathrm{C}$ ). This material is available free of charge via the Internet at http://pubs.acs.org.

\section{AUTHOR INFORMATION}

\section{Corresponding Author}

*Tel: 001-225-578-8577. Fax: 001-225-578-9162. E-mail: ywang@lsu.edu.

\section{Notes}

The authors declare no competing financial interest.

\section{ACKNOWLEDGMENTS}

This work is supported by the Ralph E. Powe Junior Faculty Enhancement Award sponsored by Oak Ridge Associated Universities (ORAU), DART2 Fund sponsored by NASALABOR, and PFund sponsored by NSF-LABOR. We would like to thank Dongsheng Guan for his assistance with ALD 
system and glovebox, Professor Rongying Jin and her student Zhenyu Diao for their help with electrical conductivity measurements, and Professor Shengming Guo's group for their help in preparing the particle pellets. We also acknowledge Materials Characterization Center (MCC) at LSU for using XRD, SEM, TEM, and XPS.

\section{REFERENCES}

(1) Manthiram, A. J. Phys. Chem. Lett. 2011, 2, 176-184.

(2) Hirayama, M.; Ido, H.; Kim, K.; Cho, W.; Tamura, K.; Mizuki, J.; Kanno, R. J. Am. Chem. Soc. 2010, 132, 15268-15276.

(3) Liu, X. M.; Huang, Z. D.; Oh, S.; Ma, P. C.; Chan, P. C. H.; Vedam, G. K.; Kang, K.; Kim, J. K. J. Power Sources 2010, 195, 42904296.

(4) Qing, C.; Bai, Y.; Yang, J.; Zhang, W. Electrochim. Acta 2011, 56, $6612-6618$

(5) Shi, J. Y.; Yi, C. W.; Kim, K. J. Power Sources 2010, 195, 68606866.

(6) Guan, D. S.; Jeevarajan, J. A.; Wang, Y. Nanoscale 2011, 3, 14651469.

(7) Sun, Y. K.; Hong, K. J.; Prakash, J. J. Electrochem. Soc. 2003, 150, A970-A972.

(8) Sun, Y. K.; Hong, K. J.; Prakash, J.; Amine, K. Electrochem. Commun. 2002, 4, 344-348.

(9) Tu, J.; Zhao, X. B.; Xie, J.; Cao, G. S.; Zhuang, D. G.; Zhu, T. J.;

Tu, J. P. J. Alloys Compd. 2007, 432, 313-317.

(10) Li, C.; Zhang, H. P.; Fu, L. J.; Liu, H.; Wu, Y. P.; Rahm, E.; Holze, R.; Wu, H. Q. Electrochim. Acta 2006, 51, 3872-3883.

(11) Li, X.; Xu, Y. J Solid State Electrochem. 2008, 12, 851-855.

(12) Li, H.; Wang, Z.; Chen, L.; Huang, X. Adv. Mater. 2009, 21, $4593-4607$.

(13) Thackeray, M. M.; Johnson, C. S.; Kim, J. S.; Lauzze, K. C.; Vaughey, J. T.; Dietz, N.; Abraham, D.; Hackney, S. A.; Zeltner, W.; Anderson, M. A. Electrochem. Commun. 2003, 5, 752-758.

(14) Wu, H. M.; Belharouak, I.; Abouimrane, A.; Sun, Y. K.; Amine, K. J. Power Sources 2010, 195, 2909-2913.

(15) Park, S. B.; Shin, H. C.; Lee, W. G.; Cho, W. I.; Jang, H. J. Power Sources 2008, 180, 597-601.

(16) Kim, J. S.; Johnson, C. S.; Vaughey, J. T.; Hackney, S. A.; Walz, K. A.; Zeltner, W. A.; Anderson, M. A.; Thackeray, M. M. J. Electrochem. Soc. 2004, 151, A1755-A1761.

(17) Lin, Y. M.; Wu, H. C.; Yen, Y. C.; Guo, Z. Z.; Yang, M. H.; Chen, H. M.; Sheu, H. S.; Wu, N. L. J. Electrochem. Soc. 2005, 152, A1526-A1532.

(18) Park, S. B.; Lee, S. M.; Shin, H. C.; Cho, W. I.; Jang, H. J. Power Sources 2007, 166, 219-225.

(19) Walz, K. A.; Johnson, C. S.; Genthe, J.; Stoiber, L. C.; Zeltner, W. A.; Anderson, M. A.; Thackeray, M. M. J. Power Sources 2010, 195, 4943-4951.

(20) Shin, D. W.; Choi, J. W.; Ahn, J. P.; Choi, W. K.; Cho, Y. S.; Yoon, S. J. J. Electrochem. Soc. 2010, 157, A567-A570.

(21) Lim, S.; Cho, J. Electrochem. Commun. 2008, 10, 1478-1481.

(22) Şahan, H.; Göktepe, H.; Patat, Ş.; Ülgen, A. Solid State Ionics 2010, 181, 1437-1444.

(23) Lee, S. W.; Kim, K. S.; Moon, H. S.; Kim, H. J.; Cho, B. W.; Cho, W. I.; Ju, J. B.; Park, J. W. J. Power Sources 2004, 126, 150-155.

(24) Liu, J. Y.; Liu, N.; Liu, D. T.; Bai, Y.; Shi, L. H.; Wang, Z. X.; Chen, L. Q.; Hennige, V.; Schuch, A. J. Electrochem. Soc. 2007, 154, A55-A63.

(25) Tu, J.; Zhao, X. B.; Cao, G. S.; Zhuang, D. G.; Zhu, T. J.; Tu, J. P. Electrochim. Acta 2006, 51, 6456-6462.

(26) Beetstra, R.; Lafont, U.; Nijenhuis, J.; Kelder, E. M.; van Ommen, J. R. Chem. Vap. Deposition 2009, 15, 227-233.

(27) Scott, I. D.; Jung, Y. S.; Cavanagh, A. S.; Yan, Y.; Dillon, A. C.; George, S. M.; Lee, S. H. Nano Lett. 2011, 11, 414-418.

(28) Shin, H. J.; Jeong, D. K.; Lee, J. G.; Sung, M. M.; Kim, J. Y. Adv. Mater. 2004, 16, 1197-1180.
(29) Kemell, M.; Pore, V.; Tupala, J.; Ritala, M.; Leskela, M. Chem. Mater. 2007, 19, 1816-1820.

(30) George, S. M. Chem. Rev. 2010, 110, 111-131.

(31) Gordon, R. G.; Hausmann, D.; Kim, E.; Shepard, J. Chem. Vap. Deposition 2003, 9, 73-78.

(32) Jung, Y. S.; Cavanagh, A. S.; Riley, L. A.; Kang, S. H.; Dillon, A. C.; Groner, M. D.; George, S. M.; Lee, S. H. Adv. Mater. 2010, 22, 2172-2176.

(33) Meng, X.; Geng, D.; Liu, J.; Li, R.; Sun, X. Nanotechnology 2011, 22,165602 .

(34) Riley, L. A.; Atta, S. V.; Cavanagh, A. S.; Yan, Y.; George, S. M.; Liu, P.; Dillon, A. C.; Lee, S. H. J. Power Sources 2011, 196, 33173324.

(35) Lee, J. T.; Wang, F. M.; Cheng, C. S.; Li, C. C.; Lin, C. H. Electrochim. Acta 2010, 55, 4002-4006.

(36) Jung, Y. S.; Cavanagh, A. S.; Dillon, A. C.; Groner, M. D.; George, S. M.; Lee, S. H. J. Electrochem. Soc. 2010, 157, A75-A81.

(37) Meng, X.; Zhong, Y.; Sun, Y.; Banis, M. N.; Li, R.; Sun, X. Carbon 2011, 49, 1133-1144.

(38) Snyder, M. Q.; Trebukhova, S. A.; Ravdel, B.; Wheeler, M. C.; DiCarlo, J.; Tripp, C. P.; DeSisto, W. J. J. Power Sources 2007, 165, 379-385.

(39) Riley, L. A.; Cavanagh, A. S.; George, S. M.; Jung, Y. S.; Yan, Y. F.; Lee, S. H.; Dillon, A. C. ChemPhysChem 2010, 11, 2124-2130.

(40) Ott, A. W.; Chang, R. P. H. Mater. Chem. Phys. 1999, 58, 132138.

(41) Elam, J. W.; George, S. M. Chem. Mater. 2003, 15, 1020-1028.

(42) Thackeray, M. M. J. Electrochem. Soc. 1995, 142, 2558-2563. 